\title{
Mechanism of trifluorothymidine potentiation of oxaliplatin- induced cytotoxicity to colorectal cancer cells
}

\author{
OH Temmink', EK Hoebe', K van der Born', SP Ackland ${ }^{2}$, M Fukushima $^{3}$ and GJ Peters ${ }^{*, 1}$ \\ 'Department of Medical Oncology, VU University Medical Center, Amsterdam, The Netherlands; ${ }^{2}$ Department of Medical Oncology, Newcastle Mater \\ Misericordiae Hospital, Waratah, NSW, Australia; ${ }^{3}$ Tokushima Research Center, Taiho Pharmaceutical Co., Tokushima, Japan
}

\begin{abstract}
Oxaliplatin (OHP) is an anticancer agent that acts by formation of Platinum-DNA (Pt-DNA) adducts resulting in DNA-strand breaks and is used for the treatment of colorectal cancer. The pyrimidine analog trifluorothymidine (TFT) forms together with a thymidine phosphorylase inhibitor (TPI) the anticancer drug formulation TAS- I02, in which TPI enhances the bioavailability of TFT in vivo. In this in vitro study the combined cytotoxic effects of OHP with TFT were investigated in human colorectal cancer cells as a model for TAS102 combinations. In a panel of five colon cancer cell lines (WiDr, H630, Colo320, SNU-C4 and SW I I I6) we evaluated the OHPTFT drug combinations using the multiple drug-effect analysis with CalcuSyn software, in which the combination index (Cl) indicates synergism $(\mathrm{Cl}<0.9)$, additivity $(\mathrm{Cl}=0.9-\mathrm{I}$. I ) or antagonism $(\mathrm{Cl}>\mathrm{I}$. I ). Drug target analysis was used for WiDr, H630 and SWI I I6 to investigate whether there was an increase in Pt-DNA adduct formation, DNA damage induction, cell cycle delay and apoptosis. Trifluorothymidine combined with $\mathrm{OHP}$ resulted in synergism for all cell lines (all $\mathrm{Cl}<0.9$ ). This was irrespective of schedule in which either one of the drugs was kept at a constant concentration (using variable drug ratio) or when the two drugs were added in a I : I $\mathrm{IC}_{50}$-based molar ratio. Synergism could be increased for WiDr using sequential drug treatment schedules. Trifluorothymidine increased Pt-DNA adduct formation significantly in $\mathrm{H} 630$ and SWIII6 (I4.4 and 99.1\%, respectively; P<0.05). Platinum-DNA adducts were retained best in SWIII6 in the presence of TFT. More DNA-strand breaks were induced in SWIII6 and the combination increased DNA damage induction (>20\%) compared with OHP alone. Exposure to the drugs induced a clear cell-cycle S-phase arrest, but was dose schedule and cell line dependent. Trifluorothymidine (TFT) and OHP both induced apoptosis, which increased significantly for WiDr and SWII 6 after TFT-OHP exposure (I 8.8 and $20.6 \%$ respectively; $P<0.05$ ). The basal protein levels of ERCCI DNA repair enzyme were not related to the DNA damage that was induced in the cell lines. In conclusion, the combination of TFT with the DNA synthesis inhibitor OHP induces synergism in colorectal cancer cells, but is dependent on the dose and treatment schedule used.
\end{abstract}

British Journal of Cancer (2007) 96, 23 I-240. doi: I 0.1038/sj.bjc.6603549 www.bjcancer.com

(C) 2007 Cancer Research UK

Keywords: apoptosis; colorectal cancer; combination studies; DNA-strand breaks; oxaliplatin; Pt-DNA adducts; trifluorothymidine

Most chemotherapy regimens used in the treatment of colorectal cancer consist of combinations of drugs to increase the therapeutic efficacy (Peters et al, 2000). The most common combinations include the fluoropyrimidine 5-fluorouracil (5FU) (Pinedo and Peters, 1988; Schmoll et al, 1999; Fishman and Wadler, 2001), together with irinotecan (CPT-11) and oxaliplatin (OHP) or more recently several targeted agents (Grivicich et al, 2001; Coutinho and Rocha Lima, 2003). For the platinum (Pt) analogue, OHP synergism with 5FU and leucovorin (LV) has been shown, whereas the drug shows little toxicity overlap and the combination has superior activity compared to 5FU/LV alone. Oxaliplatin is combined with 5FU/LV (FOLFOX and FLOX) regimens (Pelley, 2001; Andre and De Gramont, 2004; Wolmark et al, 2005), or in combination with the 5FU prodrug capecitabine (XELOX) (Cassidy et al, 2004) or CPT-11 (Goldberg et al, 2004).

Oxaliplatin is also active against other malignancies (Raymond et $a l, 1998 \mathrm{c})$, and additive or synergistic effects with other

\footnotetext{
* Correspondence: Dr GJ Peters, Department of Medical Oncology, VU University Medical Center, De Boelelaan II I7, PO box 7057, 1007 MB Amsterdam, The Netherlands; E-mail: gj.peters@vumc.nl Revised 3 November 2006; accepted 22 November 2006
}

anticancer drugs can be induced (Raymond et al, 2002). Oxaliplatin has distinct biochemical, pharmacological and cytotoxic properties compared with the related platinum compounds cisplatin and carboplatin (Rixe et al, 1996) and shows no crossresistance. All platinum compounds are cell cycle phase nonspecific and undergo nonenzymatic conversion to their active derivatives. They can react with DNA mainly by formation of PtDNA intrastrand adducts, and also by formation of interstrand and DNA - protein crosslinks, thereby blocking DNA replication and transcription (Raymond et al, 1998b; Woynarowski et al, 2000). Unlike the former two agents, OHP carries the diaminocyclohexane (DACH) ligand, which allows DNA lesions to avoid DNA mismatch repair and DNA damage recognition pathways (Fink et al, 1996; Vaisman et al, 1998). The formation of DACH-Pt-DNA adducts eventually results in DNA-strand breaks leading to the induction of apoptosis (Faivre et al, 2003; Arango et al, 2004). As $5 \mathrm{FU}$ resistance is regularly observed, other combinations enhancing OHP are of major interest to bypass 5FU resistance. Murakami et al (2000) previously showed that the fluoropyrimidine trifluorothymidine (TFT; trifluridine) was able to exert cytotoxicity against 5FU-resistant DLD-1 colon cancer cells.

Trifluorothymidine (TFT) is currently used as an antiviral agent (De Clercq, 2004) and is part of the novel oral antitumour 
drug preparation TAS-102 (Emura et al, 2004b; Tsuchiya et al, 2004; Temmink et al, 2005), which also consists of the antiangiogenic thymidine phosphorylase inhibitor TPI (Matsushita et al, 1999; Fukushima et al, 2000; Takao et al, 2000). TAS-102 is currently evaluated in different treatment schedules in phase I clinical trials (Hong et al, 2006). Trifluorothymidine acts by incorporation into DNA leading to DNA-strand breaks (Emura et al, 2004c), and by inhibition of thymidylate synthase (TS) (Eckstein et al, 1994; Temmink et al, 2004; Temmink et al, 2005), one of the major rate-limiting enzymes in DNA synthesis. In contrast to 5FU, TFT is not incorporated into RNA and does not need folates to form a ternary complex with TS. Trifluorothymidine is converted by thymidine kinase (TK) to 5trifluoro-2'-deoxythymidine- $5^{\prime}$-monophosphate (TF-TMP), which binds covalently to the active site of TS to inhibit its activity (Eckstein et al, 1994; Santi and Sakai, 1972). Thymidylate synthase inhibition results in an induction of a series of downstream events, eventually leading to cell death (Van Triest et al, 2000). These properties make TFT a suitable candidate to be combined with OHP, as both agents cause DNA damage and incorporation of TFT into DNA opposite to adenosine might affect the A-A-adduct formations.

In various colorectal cancer cell lines, we evaluated the interaction between the dual-targeted TFT and OHP in relation to formation of Pt-DNA adducts and the induction of DNA-strand breaks, cell cycle delay and apoptosis.

\section{MATERIALS AND METHODS}

\section{Materials}

Dulbecco's modified Eagle's medium (DMEM) and Hepes buffer were purchased from Cambrex BioScience (Verviers, Belgium) and foetal bovine serum (FBS) from Greiner Bio-One (Frickenhausen, Germany). Trifluorothymidine (TFT) was synthesised and provided by Taiho Pharmaceuticals Co. (Tokushima, Japan). Oxaliplatin was a gift from Sanofi-Synthelabo Inc. (Lyon, France). Sulforhodamine B (SRB) protein dye and propidium iodide (PI) were purchased from Sigma-Aldrich Chemicals (Zwijndrecht, The Netherlands). Bovine serum albumin (BSA) was obtained from Merck (Darmstadt, Germany). The PVDF membranes, ECL Hyperfilms and ECL Plus detection kit were obtained from Amersham Biosciences (Buckinghamshire, UK). The primary antibodies mouse-anti-human MLH1, MSH2, ERCC1 and $\beta$-tubulin were purchased from Zymed Lab Inc. (San Francisco, CA, USA), Oncogene Research Products (Cambridge, MA, USA), NeoMarkers Inc. (Fremont, CA, USA) and BD Biosciences (San Jose, CA, USA), respectively. The secondary peroxidase-conjugated antibodies were purchased from DAKO (Glostrup, Denmark). All other chemicals were of analytical grade and commercially available.

\section{Cell culture}

The colorectal cancer cell lines WiDr, H630, Colo320, SNU-C4 and SW1116 were used in this study. WiDr, Colo320 and SW1116 were obtained from the American Type Culture Collection (ATCC); H630 and SNU-C4 were a kind gift from Dr PG Johnston (at that time at the National Cancer Institute, Bethesda, MD, USA). All these cell lines were cultured in DMEM supplemented with $10 \%$ heat-inactivated FBS and $20 \mathrm{~mm}$ Hepes buffer (without antibiotics). They were grown as adherent monolayers in a humidified atmosphere containing $5 \% \mathrm{CO}_{2}$ at $37^{\circ} \mathrm{C}$ and were maintained in exponential growth. All cell lines except SNU-C4 are p53 mutated where no or decreased induction of p53 expression is present (Peters et al, 2002).

\section{Growth inhibition experiments and multiple drug-effect analysis}

To assess cytotoxicity of the cell lines to the drugs the SRB cytotoxicity assay was used (Skehan et al, 1990; Keepers et al, 1991). In brief, the cells were seeded in $100 \mu \mathrm{l}$ medium in triplicate in 96-well flat-bottom plates (Greiner Bio-One, Frickenhausen, Germany) in different densities depending on their growth rate (5000-10000 cells well ${ }^{-1}$ ). After $24 \mathrm{~h}, 100 \mu \mathrm{l}$ drug containing medium was added to the wells and the cells were incubated for another $72 \mathrm{~h}$. Thereafter, cells were fixed using trichloro-acetic acid (TCA) and stained with the SRB dye. Differences in optical density (OD measured at $540 \mathrm{~nm}$ ) between the treated cells and untreated control cells were compared. The percentage of control growth at the start and end of drug exposure was calculated using the formula: $\left[\left(\mathrm{OD}_{\text {treated }} / \mathrm{OD}_{\text {start drug exposure }}\right)-1\right] /\left[\left(\mathrm{OD}_{\text {control }} / \mathrm{OD}_{\text {start drug }}\right.\right.$ exposure $)-1] \times 100 \%$. The obtained $\mathrm{IC}_{25}$ and $\mathrm{IC}_{50}$ values were expressed as the concentrations that corresponded to a reduction of cellular growth by 25 and $50 \%$, respectively, when compared with values of the untreated control cells.

All cell lines were exposed to the drugs alone or in combination. Different combination variants were used to test the interaction of the drugs: either one drug was added at a concentration that caused $25 \%$ growth inhibition and the other drug was added in a concentration range, or both drugs were added in a fixed $\mathrm{IC}_{50^{-}}$ based molar ratio. To evaluate the effect of a combination of two drugs, CalcuSyn (Version 1.1.1 1996, Biosoft, Cambridge, UK) was used, a program based on the method of Chou and Talalay (Chou and Talalay, 1984). The multiple-drug effect analysis provides a numerical, statistically evaluable method, and provides classical isobolograms which give information on synergism, but no quantification.

The absorbance values of drug treated wells were compared to the absorbance values of the control wells to calculate each fraction affected (FA), where FA $=0.25$ means a decrease in absorbance and growth of $25 \%$. From the median drug-effect plots the dose that reduced absorbance by $50 \%\left(D_{\mathrm{x}}\right)$ and the slope were calculated, after which the doses of the separate drugs and combination required to induce various levels of cytotoxicity were calculated (Temmink et al, 2006). For each level of cytotoxicity, a mutually nonexclusive combination index (CI) was calculated using the formula $\mathrm{CI}=\left[(D)_{1} /\left(D_{1-\mathrm{FA}}\right)_{1}\right]+\left[(D)_{2} /\right.$ $\left.\left(D_{1-\mathrm{FA}}\right)_{2}\right]+\left[\alpha(D)_{1}(D)_{2} /\left(D_{1-\mathrm{FA}}\right)_{1}\left(D_{1-\mathrm{FA}}\right)_{2}\right]$. The parameters $(D)_{1}$ and $(D)_{2}$ represent the doses of the combination of drugs in a fixed ratio, whereas $\left(D_{1-F A}\right)_{1}$ and $\left(D_{1-F A}\right)_{2}$ are the doses of the individual drugs resulting in the effect $1-\mathrm{FA}(\alpha=1$ for mutually nonexclusive drugs). The $\mathrm{CI}$ indicates synergism $(\mathrm{CI}<0.9)$, additivity $(\mathrm{CI}=0.9-1.1)$ or antagonism $(\mathrm{CI}>1.1)$. A mean $\mathrm{CI}$ was calculated from data points with $\mathrm{FA}>0.5$ for the combinations in which one drug was added at a constant concentration, and from the FA values $0.6,0.75$ and 0.9 for the fixed ratio combinations. The FA range used to calculate the average $\mathrm{CI}$ values in the combination experiments did not include CI values of $\mathrm{FA}<0.5$, which was considered as not relevant growth inhibition (Peters et al, 2000), because one aims to achieve the maximal effect of the drugs tested on cancer cells. Furthermore, CI values at FA $>0.9$ were not taken into account owing to higher chance to subject to error, and because this would not add much more information. Averaging the CI values for the whole FA=01-0.9 range might also lead to false interpretation of the data, and different effects were seen at different FA values (Figure 2B).

\section{Determination of platinum-DNA adduct formation}

The formation of Pt-DNA adducts into DNA after exposure of cells to OHP was measured using a protocol adapted from Van Moorsel et al (1999). Cells were grown to $70-80 \%$ confluence in $75 \mathrm{~cm}^{2}$ tissue culture flasks (Greiner Bio-One) and then treated with 
$200 \mu \mathrm{m}$ OHP for $24 \mathrm{~h}$ at $37^{\circ} \mathrm{C}$, either alone or in combination with $10 \mu \mathrm{M}$ TFT ( $4 \mathrm{~h}$ preincubation or/and simultaneous exposure), to investigate whether TFT influenced Pt-DNA adduct formation induced by OHP. Thereafter, the cells were either harvested or cultured in drug-free medium for another $3 \mathrm{~h}$. After washing with phosphate-buffered saline (PBS), trypsinising and harvesting the cells, the cell pellets (at least $5 \times 10^{6}$ cells) were resuspended in icecold DNA STAT-60 lysis reagent (Tel-Test Inc., Friendswood, TX, USA; $5 \times 10^{6}$ cells $1 \mathrm{ml}^{-1}$ ). The DNA extraction, precipitation and washing steps were carried out according to the protocol of the manufacturer. The obtained DNA pellets were dissolved in a TE buffer (10 mM Tris, $1 \mathrm{~mm}$ EDTA; $\mathrm{pH}$ 8.0). DNA content was estimated by measuring optical densities with the NanoDrop apparatus (NanoDrop Technologies Inc., Wilmington, DE, USA). All samples had an $\mathrm{OD}_{260} / \mathrm{OD}_{280}$ ratio $>1.9$ indicating uncontaminated DNA. Sodium chloride $(1.65 \mathrm{M})$ was added in a volume of 0.1 to the dissolved DNA. A calibration curve was made using different solutions of OHP $(0-2 \mu \mathrm{M})$. The Pt content of the samples and standards (expressed as pmol $\mu \mathrm{g}^{-1}$ DNA) was measured using Atomic Absorption Spectrometry (AAS).

\section{Comet DNA damage assay}

The alkaline comet assay or single-cell gel electrophoresis assay was performed to detect DNA-strand breaks associated with DNA damage (Olive and Banath, 1997; Olive, 2002). The assay is based on the alkaline lysis of labile DNA at damaged sites where denatured and cleaved DNA fragments migrate easily out of the cell under the influence of an electric field than undamaged DNA. To study the role of DNA damage in the interaction between OHP and TFT, we exposed $1.6 \times 10^{5}$ cells in six-well plates to $\mathrm{IC}_{90}$ of the drugs for $24 \mathrm{~h}$. This concentration caused $90 \%$ growth inhibition in the $72 \mathrm{~h}$ growth inhibition studies. As positive controls, cells were exposed to $100 \mu \mathrm{M} \mathrm{H}_{2} \mathrm{O}_{2}$ for $20 \mathrm{~min}$ at $4{ }^{\circ} \mathrm{C}$ to induce significant oxidative damage. Untreated cells were used as negative controls. The cell suspensions consisted of $8 \times 10^{4} \mathrm{cells} \mathrm{ml}^{-1}$ in PBS. The lysis, electrophoresis and staining procedures were previously described (Hartley et al, 1999).

After the PI staining procedure, the slides were rinsed in distilled water and viewed within $24 \mathrm{~h}$. The DNA from the cells was visualised using a Zeiss Axioskop2 fluorescence microscope (Carl Zeiss Mikroscopie, Jena, Germany) with a Zeiss HBO-103W/2 mercury light source (using $546 \mathrm{~nm}$ light excitation filter). The microscope was attached to a Zeiss AxioCam MRm Camera using an Achroplan $\times 20$ objective. The obtained comet images were analysed using Scion Image software (Scion Corp., Frederick, MD, USA). DNA damage was quantified as the tail moment, the product of the percentage of total DNA in the comet tail and the mean distance between the head and tail distributions (Hartley et al, 1999). At least 20 comets were analysed per slide.

\section{Apoptosis analysis}

The terminal deoxynucleotidyl transferase (-TdT-)mediated dNTPlabelling (TUNEL) method was used for the detection of cells undergoing apoptosis. For this purpose we used the TdT-DNAFragment End Labeling Kit (FragEL ${ }^{\mathrm{TM}}$; Calbiochem, Oncogene Research Products, Cambridge, MA, USA). In this method, TdT binds to exposed $3^{\prime}-\mathrm{OH}$ ends of DNA fragments generated in apoptotic cells in order to add biotin-(un)labeled dNTPs, which are detected using a streptavidin-horseradish peroxidase conjugate. Cells were plated into 6-wells plates as described in the cell cycle analysis section and were exposed $48 \mathrm{~h}$ or $72 \mathrm{~h}$ to $\mathrm{IC}_{75}$ of $\mathrm{OHP}$ or/and TFT (with or without a $24 \mathrm{~h}$ TFT preincubation period). After the incubation period cytospin slides were made using a formaldehyde fixation protocol. The staining was performed according to the manufacturer's recommended procedure. Cells stained positive with $3^{\prime}-3^{\prime}$-diaminobenzidine (DAB) produce a brownish colour, whereas nonreactive cells were counterstained with methylgreen. Actinomycin D-treated HL60 cells were included in the kit and served as positive controls. Negative controls were cytospins of untreated cells in their logarithmic growth phase. Using light microscopy, 1000 cells were counted twice for positive/negative staining on randomly selected areas on the glass slide, and the apoptotic index was calculated as the percentage of positive staining cells. Cells were defined as apoptotic when the (major part of) nuclear area was DAB-labelled.

\section{Cell cycle analysis}

Cell cycle distribution was measured on cells exposed to the drugs alone or in combination (Cloos et al, 2002). On day 0, a series of six-well plates were filled with $2 \mathrm{ml}$ cell suspensions at a concentration of $2 \times 10^{5}$ cells well $^{-1}$. After $24 \mathrm{~h}$ incubation, cells were exposed $48 \mathrm{~h}$ to $\mathrm{IC}_{50}$ or $\mathrm{IC}_{75}$ concentrations of the drugs alone or in combination (with or without a $4 \mathrm{~h}$ TFT preincubation period). Pilot experiments demonstrated that the optimal exposure time was $48 \mathrm{~h}$. The percentage of cells in the different cell cycle phases $\left(G_{1}, S\right.$ and $\left.G_{2} M\right)$ was measured using FACScan (Becton Dickinson Immunocytometry Systems, San Jose, CA, USA). For each measurement, 20000 cells were counted, and each sample was assayed in duplicate. For calculation of the cell cycle distribution, the Becton Dickinson's CellQuest software was used.

\section{Western blot analysis}

Frozen pellets of the cell lines were lysed in buffer $(0.1 \%$ Triton X$100,150 \mathrm{~mm} \mathrm{NaCl}, 10 \mathrm{~mm}$ Tris- $\mathrm{HCl}, 50 \mathrm{~mm} \beta$-glycerophosphate; $\mathrm{pH}$ 7.5) and sonificated $5 \times 5 \mathrm{~s}$ with $5 \mathrm{~s}$ intervals. After centrifugation $\left(10 \mathrm{~min} 13000 \mathrm{~g}\right.$ at $\left.4^{\circ} \mathrm{C}\right)$, the supernatants were measured for protein content using the BioRad Bradford protein assay (Bradford, 1976). For determination of protein expression, $20 \mu \mathrm{g}$ of total protein from each cell line was loaded and separated on a $10 \%$ SDS-PAGE gel, followed by blotting on a PVDF membrane. Each membrane was preincubated $\mathrm{O} / \mathrm{N}$ at $4{ }^{\circ} \mathrm{C}$ with blocking buffer ( $5 \%$ milk powder in $0.15 \mathrm{M} \mathrm{NaCl}, 0.05 \%$ Tween-20, $10 \mathrm{~mm}$ Tris- $\mathrm{HCl}$ (TBS-T); $\mathrm{pH}$ 8.0) to prevent aspecific antibody binding. This was followed by $2 \mathrm{~h}$ incubation at room temperature with the primary antibodies diluted in TBS-T containing 5\% BSA. After three $10 \mathrm{~min}$ washing steps with TBS-T, the blots were incubated for $1 \mathrm{~h}$ at room temperature with the secondary antibodies diluted in TBS-T containing $2 \%$ milk powder. Detection of antibody binding was measured with enhanced chemoluminescence (ECL Plus detection solution and ECL Hyperfilms). Protein levels were determined by densitometric scanning.

\section{Statistical evaluation}

The (un)paired Student's $t$-test was used for statistical evaluation of the results. Changes were considered to be significant when $P<0.05$.

\section{RESULTS}

\section{Evaluation of the combination OHP with TFT}

The sensitivities of the colorectal cancer cell lines for OHP and TFT varied considerably (Table 1). SNU-C4 was most sensitive to OHP; H630 and Colo320 were most sensitive to TFT. WiDr was most resistant to OHP, whereas SW1116 was the most TFT-resistant cell line. The obtained $\mathrm{IC}_{50}$ values were also used to calculate the drug ratios for the fixed ratio combinations.

Multiple drug-effect analysis was performed for the combinations of TFT with OHP using the CalcuSyn software. Figure 1 shows representative growth inhibition curves with SW1116 cells for the combinations using a variable concentration of OHP and a 
Table I Growth inhibition of TFT and OHP for the colorectal cancer cell lines

\begin{tabular}{lcc}
\hline Cell line & TFT & OHP \\
\hline WiDr & $2025 \pm 527^{\mathrm{a}}$ & $6000 \pm 577$ \\
H630 & $453 \pm 114^{\mathrm{a}}$ & $773 \pm 37$ \\
Colo320 & $533 \pm 133^{\mathrm{a}}$ & $2083 \pm 309$ \\
SNU-C4 & $830 \pm 214$ & $308 \pm 4$ \\
SWII16 & $7450 \pm 1340$ & $1128 \pm 189$ \\
\hline
\end{tabular}

Cells were exposed to a concentration range of TFT or OHP for $72 \mathrm{~h}$. Values $\left(\mathrm{IC}_{50}\right.$ in nM) are means \pm s.e.m. of $3-5$ experiments ${ }^{a}$ Results are partly published (Temmink et al, 2005).

fixed concentration of TFT, illustrating at least additive cytotoxicity. Dose-effect and FA-CI plots illustrating the effects of TFT - OHP fixed drug ratio combinations are depicted in Figure 2. Figure 2A depicts growth inhibition curves of $\mathrm{H} 630$ cells exposed to OHP and TFT at various concentrations based on a $1: 1 \mathrm{IC}_{50}$ ratio, and clearly shows that the combination causes more growth inhibition than each drug alone. To indicate the effects at different FA values average $\mathrm{CI}$ values were calculated for each FA. Figure 2B shows the mathematical analysis of these data and demonstrates synergism at FA $>0.5$ for $\mathrm{H} 630$, as well as the other cell lines. The FA values were obtained after exposure of cells to a series of drug concentrations of TFT and/or OHP, depending on the combination variant. The mean $\mathrm{CI}$ values of the fixed ratio TFT-OHP combination variants are shown in Figure 3. The effects of these combinations were synergistic in the cell lines (all CI $<0.9$ ). For the variable drug ratio combinations, only in Colo320 (TFTc; mean $\mathrm{CI}=0.98 \pm 0.08)$ and SNU-C4 (OHPc; mean $\mathrm{CI}=0.94 \pm 0.16)$ the interaction between the drugs was not more than additive. The extent of synergism differed according to the cell line and combination variant. Strongest synergism was observed with SW1116 cells for all three combination variants $(0.43 \leqslant$ mean $\mathrm{CI} \leqslant 0.64)$. For further evaluation of the TFT-OHP combination, only the cell lines WiDr, H630 and SW1116 were used, because for these cell lines large differences in drug sensitivity were found. Incubating these cells the first $24 \mathrm{~h}$ with only TFT or OHP decreased synergism for the $1: 1$ ratio combinations for $\mathrm{H} 630$ and SW1116 ( $0.6 \leqslant$ mean $\mathrm{CI} \leqslant 1.2$; data not shown), but not for WiDr, where increased synergism was observed for both sequential combinations (Figure 4); TFT preincubation decreased the mean $\mathrm{CI}$ to 0.6 compared to the simultaneous combination (mean $\mathrm{CI}=0.81 \pm 0.06)$, whereas OHP preincubation decreased the mean CI to 0.4 .

\section{Formation of Pt-DNA adducts}

Because the synergism might be related to an influence of TFT on OHP-induced DNA damage by affecting the accumulation of Pt-DNA adducts, we studied the formation and retention of Pt-DNA adducts in three cell lines. The cell lines were selected, because one is rather insensitive to OHP (WiDr) or TFT (SW1116) or sensitive to both drugs (H630). As WiDr and SW1116 have an intermediate sensitivity to the other drugs, we reasoned that this panel would be representative for all five cell lines, also because the synergism patterns were similar. The measurements were limited to Pt-DNA adduct formation. Total uptake of OHP in cells was not measured, as it was considered unlikely that a nucleoside analogue would affect uptake of a platinum compound into a cell, because transport mechanisms for platinum analogs are not affected by nucleoside analogs, but Pt-DNA adduct formation and repair are (Bergman et al, 1996; Van Moorsel et al, 1999; Yang et al, 2000). With OHP alone adduct formation ranged from 1.8 to $2.6 \mathrm{pmol} \mu \mathrm{g}^{-1}$ DNA (Figure 5). Pretreatment with $10 \mu \mathrm{M}$ TFT decreased the formation of Pt-DNA adducts by $13 \%$ or more.

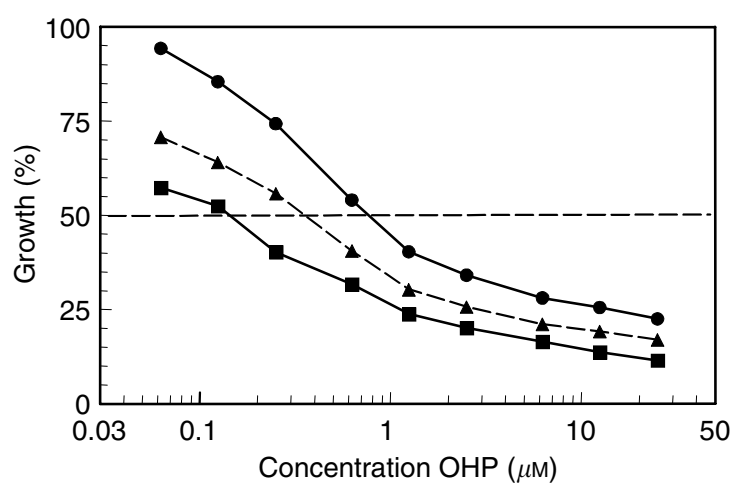

Figure I Representative growth inhibition curves for the combination OHP-TFT using a variable drug ratio. SW I I 6 cells were exposed $72 \mathrm{~h}$ to $\mathrm{OHP}$, TFT or OHP + TFT in which OHP was added at various concentrations (OHPv) and TFT was kept at a constant $\mathrm{IC}_{25}$ concentration (TFTc). Filled circles and solid line, OHPv; filled triangles and broken line expected growth inhibition calculated from the single drug doses; filled squares and solid line, OHPv + TFTc. The growth inhibition curves were obtained from three separate experiments. Per experiment, an average C value was calculated from all data points with $F A>0.5$. In this example, mean $\mathrm{Cl}=0.64$. All s.e.m. values $<10 \%$
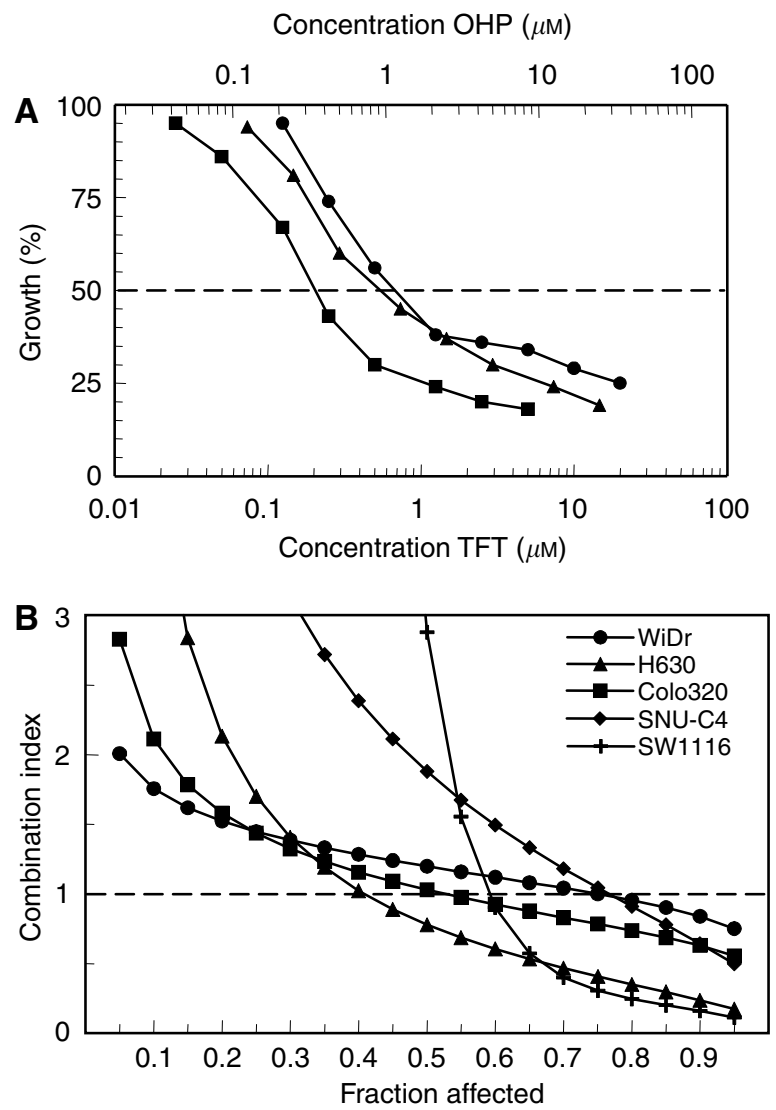

Figure 2 Illustrative growth inhibition curves $(\mathbf{A})$ and $\mathrm{FA}-\mathrm{Cl}$ plots $(\mathbf{B})$ for the combination OHP-TFT using a fixed drug ratio. Figure A: H630 cells were exposed $72 \mathrm{~h}$ to TFT (filled circles), OHP (filled triangles) or TFT + OHP (filled squares). Figure B: Average $\mathrm{Cl}$ values calculated from each FA for all five cell lines used in the study. Per experiment, an average $\mathrm{Cl}$ value was calculated from data-points with $\mathrm{FA}=0.6,0.75$ and 0.9 . All s.e.m. values of data points $<15 \%$.

Simultaneous treatment resulted in a significant increase in the formation of Pt-DNA adducts in H630 and SW1116 (14.4 and $99.1 \%$, respectively; $P<0.05)$, but not in WiDr. However, TFT 


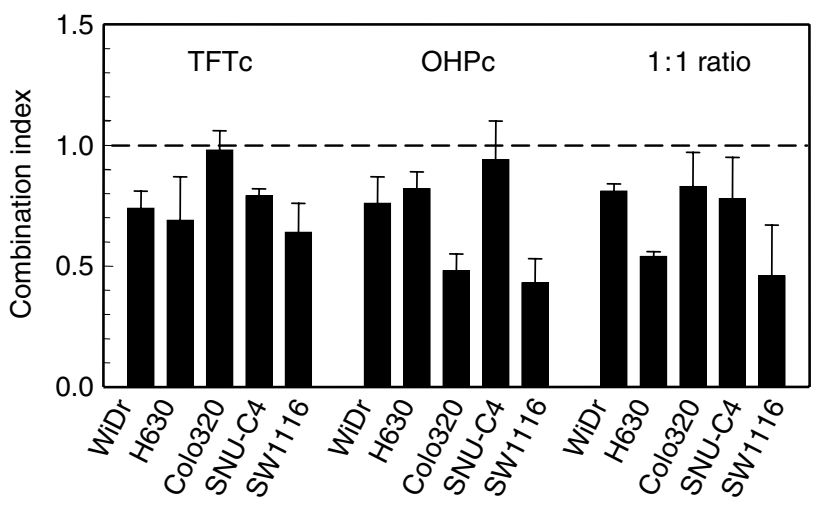

Figure 3 Synergy analysis of OHP combined with TFT for the colorectal cancer cell lines. Interpretation of $\mathrm{Cl}$ values: $\mathrm{Cl}<0.9$ means synergism; $\mathrm{Cl}=0.9-1.1$ means additive; $\mathrm{Cl}>1.1$ means antagonism. TFTc: combination of the drugs in which TFT was kept at a constant concentration $\left(\mathrm{IC}_{25}\right)$; OHPc: combination of the drugs in which OHP was kept at a constant concentration $\left(\mathrm{IC}_{25}\right)$; I:I ratio: the two drugs were added in a fixed I:I $\mathrm{IC}_{50}$-based molar ratio. A mean $\mathrm{Cl}$ was calculated from data points with FA $>0.5$ for the combinations with variable drug ratio, and from the FA values $0.6,0.75,0.9$ for the fixed ratio combinations. Values (mean $\mathrm{Cl} \pm$ s.e.m.) are based on 3-4 separate experiments. See also Materials and Methods.

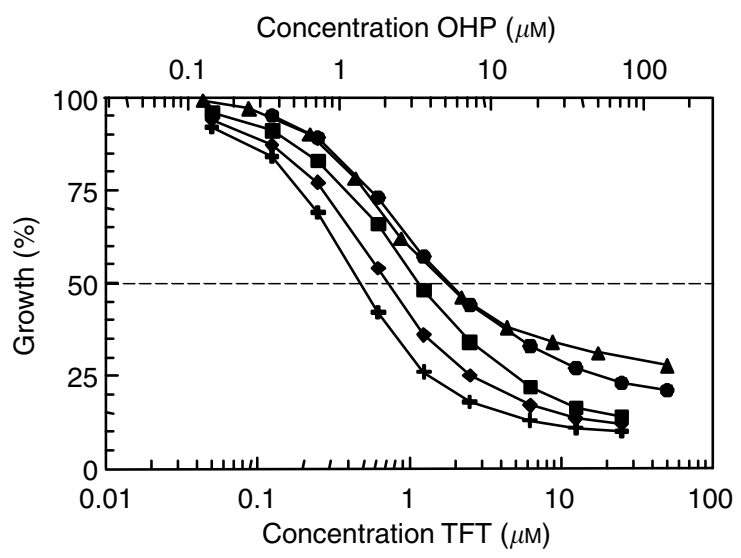

Figure 4 Representative growth inhibition curves for simultaneous and sequential OHP-TFT combinations using a fixed drug ratio. WiDr cells were exposed $72 \mathrm{~h}$ to OHP with or without TFT in different schedules: TFT alone (filled circles), OHP (filled triangles), TFT + OHP (filled squares), $24 \mathrm{~h}$ TFT alone $>48 \mathrm{~h}$ TFT + OHP (filled diamonds), $24 \mathrm{~h}$ OHP alone $>48 \mathrm{~h}$ TFT + OHP (filled crosses). The growth inhibition curves were obtained from 3-5 separate experiments (all s.e.m. values <15\%). Per experiment an average $\mathrm{Cl}$ value was calculated from all data points with $\mathrm{FA}>0.5$.

pretreatment decreased the Pt-DNA adduct formation $(>6 \%)$. The formed Pt-DNA adducts after exposure to OHP alone were best retained in the SW1116 cells (81.6\%) compared with H630 and $\mathrm{WiDr}(<56 \%)$, and TFT treatment increased this in the latter two cell lines $(>10 \%)$.

\section{Formation of DNA-strand breaks and induction of apoptosis}

Using the comet assay, we evaluated whether more DNA damage was induced in the cells after $24 \mathrm{~h}$ exposure to a combination of TFT-OHP at their $\mathrm{IC}_{90}$ concentrations compared to each drug alone (Figure 6). The WiDr, H630 and SW1116 cell lines were used
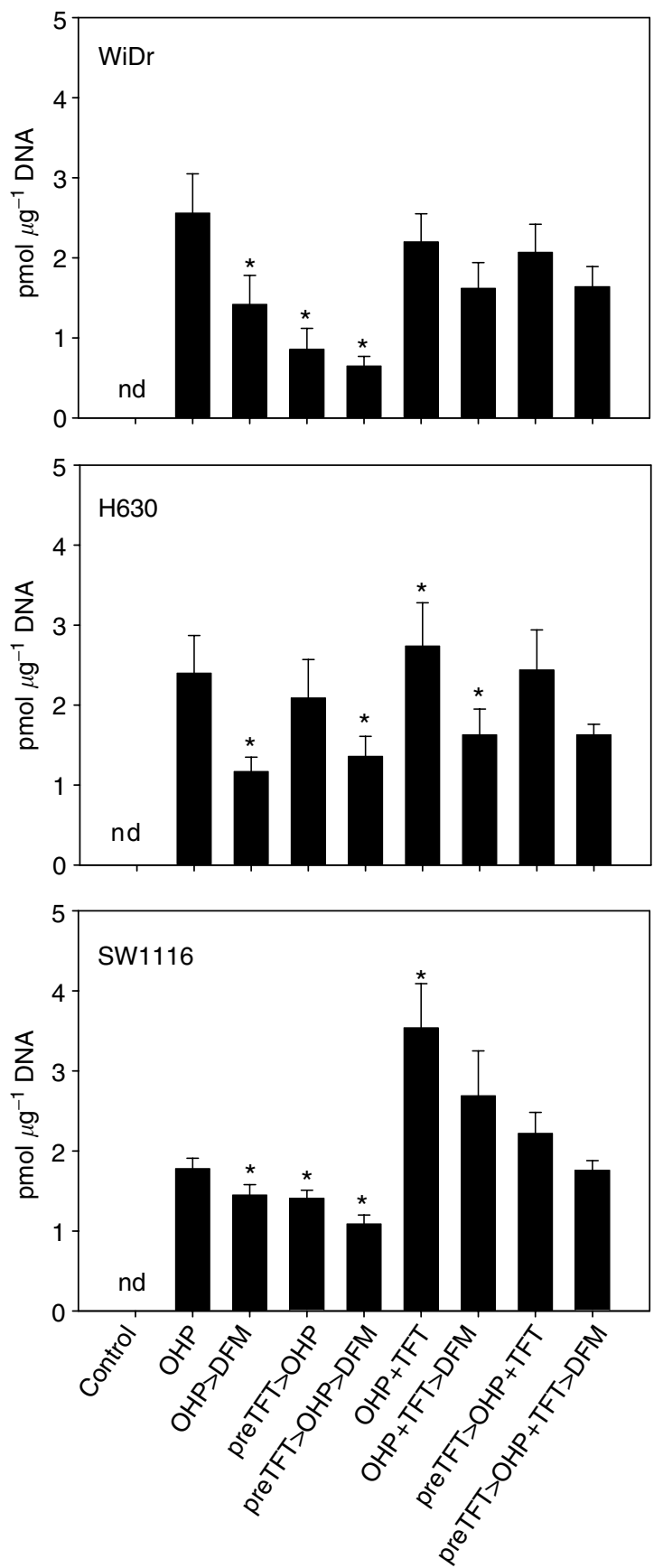

Figure 5 Pt-Adduct formation in DNA after exposure of WiDr, H630 and SWIII 6 cells to OHP with or without TFT in different schedules. The cell lines were exposed $24 \mathrm{~h}$ to $200 \mu \mathrm{M}$ OHP alone or with $10 \mu \mathrm{M}$ TFT, either simultaneously and/or with a $4 \mathrm{~h}$ preincubation period (preTFT). To determine retention of the formed Pt adducts the cells were incubated an additional $3 \mathrm{~h}$ in drug-free medium (DFM). Values are Means \pm s.e.m. $(n=4)$. $* P<0.05$ compared to $24 \mathrm{~h}$ OHP. nd = nothing detected.

because the combinations induced synergistic cytotoxicity in these cells. Relatively high concentrations of the drugs were chosen to determine the potency of this combination to induce DNA damage in the cells. The calculated tail moment represents DNA-strand break formation induced by the drugs. At equally growth inhibitory concentrations there was consistently more DNA damage in the cells after exposure to OHP compared to TFT, although not significantly $(P>0.05)$. About $20-30 \%$ more DNA 


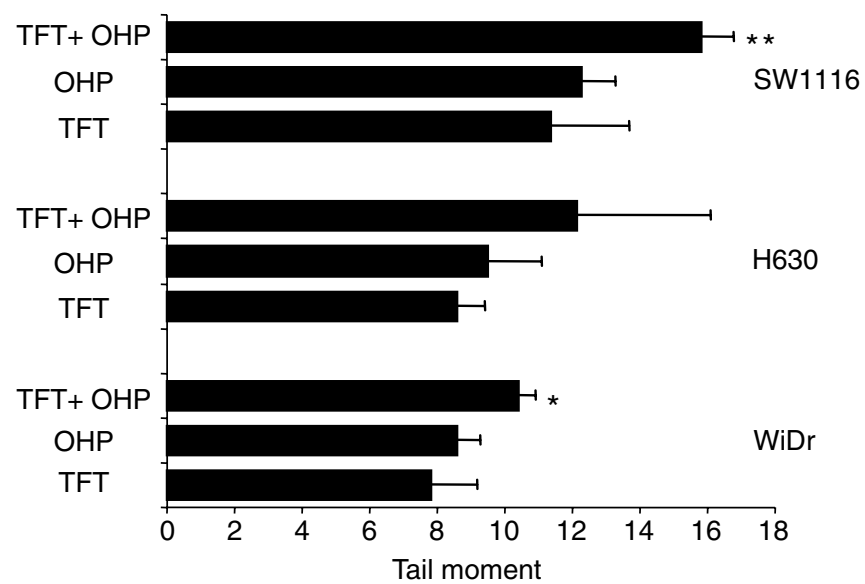

Figure 6 DNA damage induction in WiDr, H630 and SWIII6 cells using the Comet assay. The cells were exposed $24 \mathrm{~h}$ to [IC $\left.\mathrm{C}_{90}\right] \mathrm{OHP}$ or [IC90] TFT alone or in combination. These concentrations were: WiDr: $75 \mu \mathrm{M}$ TFT, $75 \mu \mathrm{M}$ OHP; H630: $50 \mu \mathrm{M}$ TFT, $30 \mu \mathrm{M}$ OHP and SWIII6: $200 \mu \mathrm{M}$ TFT, $80 \mu \mathrm{M}$ OHP. Values are means \pm s.e.m. $(n=3)$. Significant differences compared with $\mathrm{OHP}$ alone: $* P<0.05$; $* * P<0.0$ I (paired $t$-test).

damage was induced after exposure to TFT-OHP compared to OHP alone. Most DNA-strand breaks were induced in SW1116 cells (mean tail moment of $15.8 \pm 0.5$ ). Comparable results were seen after exposure to $\mathrm{IC}_{75}$ concentrations of the drugs (all mean tail moments $<10$; data not shown).

Table 2 summarises the results of apoptosis induction using the TUNEL apoptosis assay when the cells were exposed $72 \mathrm{~h}$ to $\mathrm{IC}_{75}$ concentrations of the drugs. In the control samples, less than $3 \%$ apoptosis was found in the total cell population. When the cells were exposed to OHP alone or TFT alone, about equal amounts of apoptosis were induced (range $6.7-16.2 \%$ apoptotic cells). This was at least 3.7-fold higher compared with the controls. After TFT-OHP drug treatment most apoptosis was induced in the WiDr and SW 1116 cell populations (18.8 and $20.6 \%$, respectively), with less in H630 cells; in each cell line, TFT-OHP induced significantly more apoptosis compared with OHP alone $(P<0.05)$. Shortening the total exposure to OHP by $24 \mathrm{~h}$ decreased the induction of apoptosis by at least $30 \%$ for all cell lines. A TFT preexposure period of $24 \mathrm{~h}$, followed by $48 \mathrm{~h}$ OHP exposure, increased apoptosis induction slightly compared to $48 \mathrm{~h}$ OHP exposure, but this was still significantly lower compared with $72 \mathrm{~h}$ TFT-OHP exposure (at least 45\%; $P<0.01$ ). Induction of apoptosis was generally in agreement with the results obtained from the DNA damage experiments.

\section{Induction of cell cycle arrest}

The combination TFT-OHP was also evaluated using flow cytometry analysis to determine the cell cycle distribution after $48 \mathrm{~h} \operatorname{drug}(\mathrm{s})$ exposure (Table 3 ). This time point was chosen because at $48 \mathrm{~h}$ substantial changes can be seen in cell cycle distribution, which are not yet observed after $24 \mathrm{~h}$ exposure. Trifluorothymidine induced an S-phase arrest, or $\mathrm{G}_{2} \mathrm{M}$-phase arrest, although this was concentration-, schedule- and cell linedependent. In all cell lines TFT or OHP induced a clear reduction in the $\mathrm{G}_{1}$-phase cell population, probably owing to DNA synthesis inhibition. This was more pronounced after TFT exposure than after OHP exposure. For all three cell lines a significant increase in the $S$ phase cell population was seen after exposure to TFT or OHP alone $(6.2-44.7 \% ; P<0.05)$. Only in WiDr cells TFT induced a clear S-phase arrest whereas OHP induced a $\mathrm{G}_{2} \mathrm{M}$-phase arrest (both $>50 \%$ ). The combination TFT-OHP induced a strong
Table 2 Induction of apoptosis by OHP, TFT or both drugs in WiDr, $\mathrm{H} 630$ and SWIII6 cells

\begin{tabular}{|c|c|c|c|}
\hline \multirow[b]{2}{*}{ Drug Treatment } & \multicolumn{3}{|c|}{ Cell line } \\
\hline & WiDr & H630 & SWIII6 \\
\hline Control & $2.3 \pm 0.6 * *$ & $1.6 \pm 0.3 * *$ & $2.9 \pm 0.2 * *$ \\
\hline TFT IC $7572 \mathrm{~h}$ & $16.2 \pm 2.5$ & $6.7 \pm 0.5 * *$ & $10.6 \pm 1.7$ \\
\hline $\mathrm{OHP} I \mathrm{C}_{75} 72 \mathrm{~h}$ & $13.2 \pm 1.7$ & $8.2 \pm 3.0$ & $13.7 \pm 2.2$ \\
\hline $\mathrm{OHP} I \mathrm{C}_{75}+\mathrm{TFT} I \mathrm{C}_{75} 72 \mathrm{~h}$ & $\mid 8.8 \pm 3.1 *$ & $13.1 \pm 1.0 *$ & $20.6 \pm 1.5 * *$ \\
\hline $\mathrm{OHP} I \mathrm{C}_{75} 48 \mathrm{~h}$ alone & $8.9 \pm 1.2 *$ & $3.5 \pm 0.3 * *$ & $7.0 \pm 0.7 * *$ \\
\hline TFT IC $7524 \mathrm{~h}>\mathrm{OHP} \mathrm{IC}_{75} 48 \mathrm{~h}$ & $9.3 \pm 1.1 *$ & $7.0 \pm 0.7 *$ & $9.0 \pm 0.9 *$ \\
\hline
\end{tabular}

The cells were exposed $72 \mathrm{~h}$ to $\left[\mathrm{IC}_{75}\right]$ of the drugs, either alone or in combination. These concentrations were: WiDr: $25 \mu \mathrm{M}$ TFT, $10 \mu \mathrm{M}$ OHP; H630: $10 \mu \mathrm{M}$ TFT, $3.5 \mu \mathrm{M}$ OHP and SWIII6: $100 \mu \mathrm{M}$ TFT, $10 \mu \mathrm{M}$ OHP. Values (\%) represent [apoptosis population]/[total cell population] and are expressed as means \pm s.e.m. $(n=3)$. Compared to OHP alone: $* P<0.05$; $* * P<0.01$ ((un)paired $t$-test).

S-phase arrest for all cell lines $(P<0.01)$. Compared to OHP exposure, the combination significantly increased the $S$-phase cell population for WiDr and H630, in contrast to SW1116, where TFT did not increase (\%) cells in the S-phase, but (\%) cells in $\mathrm{G}_{2} \mathrm{M}$ phases was increased from $27.8 \%$ to $38.1 \%(P<0.05)$. The $\mathrm{G}_{1}$ population was also more decreased $(\geqslant 6.2 \%)$. A $4 \mathrm{~h}$ TFT preincubation period hardly affected cell cycle distribution induced by OHP, except for SW1116, where $G_{2} M$ population increased from 27.8 to $51.3 \%$; $(P<0.01)$. Surprisingly, this result was not observed in the growth inhibition and apoptosis experiments. Comparable results were obtained when cells were exposed to $\mathrm{IC}_{50}$ concentrations of the drugs, but induction of Sphase arrest was less potent (data not shown).

\section{Protein levels of DNA repair enzymes}

Figure 7 shows the basal expression of ERCC1, MLH1 and MSH2 DNA repair proteins for the colorectal cancer cell lines. There was no direct correlation with OHP or TFT sensitivity. For example, SW1116 is more sensitive to the drug combination compared to WiDr, inducing significantly more DNA-strand breaks in these cells, but also has higher ERCC1 levels, which is part of the DNA excision repair system, which is mainly involved in the repair of OHP-induced DNA damage.

\section{DISCUSSION}

In the present study we demonstrated synergism between OHP and TFT, which was found for drug combinations using either variable or fixed drug ratios. The most pronounced effects were seen in SW1116 cells, where strong synergism was induced at high effect levels. There is a parallel enhancement of OHP-induced DNA damage and apoptosis by TFT. We have demonstrated that this damage may be explained by increased formation of Pt-DNA adducts, which possibly is related to increase incorporation of TFT into the DNA.

The platinum compound OHP is currently routinely used in the treatment of colorectal cancer patients in combination with 5FU (or its prodrug capecitabine). In the case of 5FU resistance, it may also be combined with irinotecan (CPT-11), thereby improving response and survival rates (Maindrault-Goebel et al, 1999; Coutinho and Rocha Lima, 2003; Andre and De Gramont, 2004; Smorenburg et al, 2006). Oxaliplatin acts by effectively disrupting the DNA replication and transcription in the cell, but the downstream molecular events underlying its mechanism of action have not been characterised very well (Arango et al, 
Table 3 Cell cycle distribution of WiDr, H630 and SWIII6 cells following OHP and/or TFT exposure

Cell cycle distribution

Drug treatment

(\%) G I

(\%) S

(\%) G2M

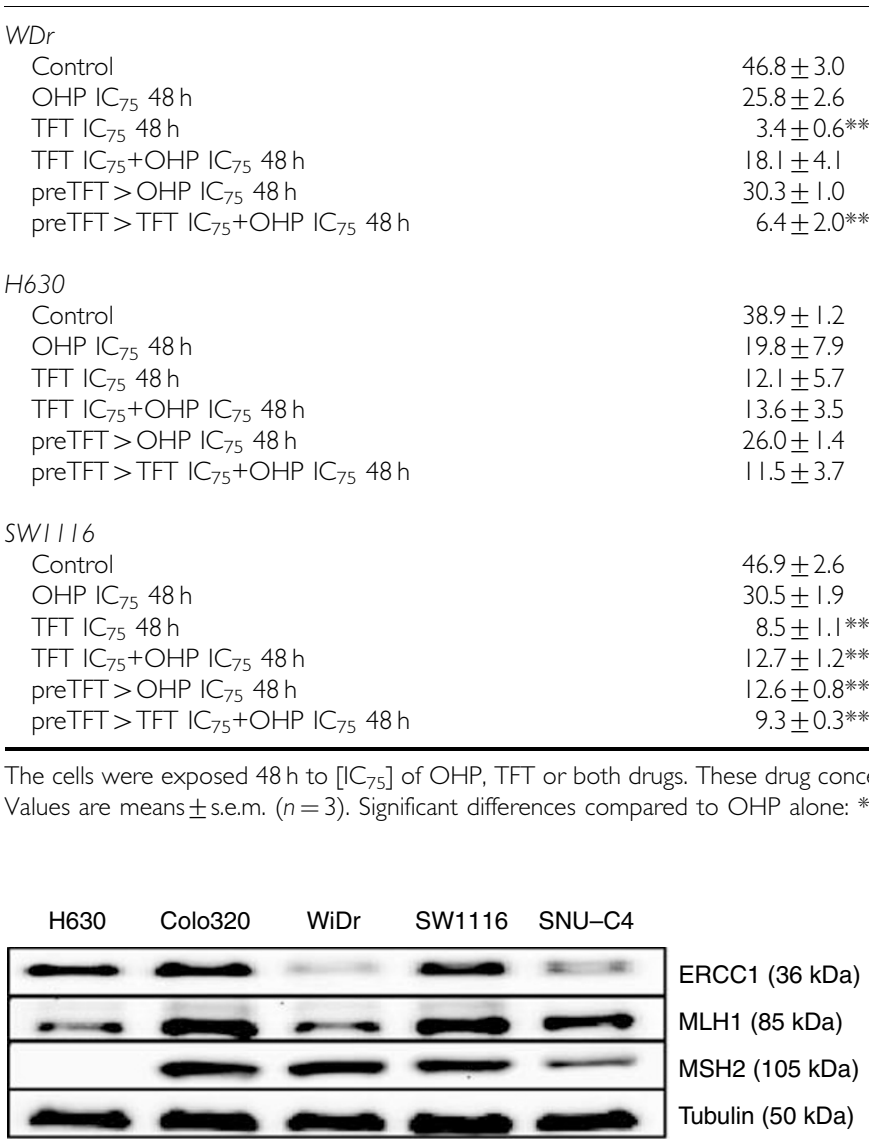

Figure 7 Basal protein levels of the DNA repair enzymes ERCCI, MLHI and $\mathrm{MSH}_{2}$ for the colorectal cancer cell lines H630, Colo320, WiDr, SWIII 6 and SNU-C4. Equal protein amounts from unexposed cells were used for Western blotting as described in the Materials and Methods section.

2004). Oxaliplatin (OHP) itself reduces growth of the cells at clinically relevant concentrations, which can be associated with a $\mathrm{G}_{2} \mathrm{M}$-phase arrest in the cell cycle (Raymond et al, 2002) and increased induction of apoptosis (Tassone et al, 2002). Inducing cell death by chemotherapeutics is an important terminal mechanism to eliminate malignant cells in vivo (Broker et al, 2005). Trifluorothymidine was able to enhance OHP-induced apoptotic cell death, possibly owing to extensive DNA damage induction by increased Pt-DNA adduct formation.

In preclinical studies using colorectal cancer cells, OHP has been combined with a variety of anticancer metabolites to improve its killing efficacy, such as TS inhibitors (Raymond et al, 1997), taxanes and topoisomerase I inhibitors (Raymond et al, 1998a; Raymond et al, 2002). Trifluorothymidine, in the form of the orally administered TAS-102 formulation, might be a good alterntive to $5 \mathrm{FU}$ in the combination with OHP. Trifluorothymidine incorporation into DNA also induces DNA-strand breaks, and as a result of intracellular thymidine depletion owing to inhibition of TS, misincorporation of uracil into DNA occurs, thereby enhancing the induction of DNA damage (Webley et al, 2001). Trifluorothymidine itself is a dual-targeted agent, and the other part of TAS-102 is TPI, which is a potent TP inhibitor $\left(K_{i}=0.17 \mathrm{nM}\right)$ (Fukushima et al, 2000). In vivo, TFT is very dependent on TP activity, since adding TPI enhances bioavailability of TFT (Emura et al, 2005), which may favour the combination OHP-TFT, possibly leading to more DNA damage in cells and higher cytotoxicity. Secondly, TP is also known as PD-ECGF (Moghaddam and Bicknell, 1992; Sumizawa et al, 1993), which has stimulating properties on blood vessel formation in solid tumours (Takahashi et al, 1998). Previous studies showed that TPI inhibits blood vessel formation, thereby increasing apoptosis (Matsushita et al, 1999) and suppressing the formation of metastases (Takao et al, 2000). In contrast to 5FU-based formulations, the orally given TAS-102 has both cytotoxic and antiangiogenic properties.

Trifluorothymidine and 5FU are both potent TS inhibitors, but in contrast to TFT, 5FU is also incorporated into the RNA of cancer cells (Peters, 2002). Furthermore, TFT can only be activated by TK, thus decreased TK activity will affect TFT conversion to TF-TMP, and subsequently leads to decreased TS inhibition and TF-TTP incorporation into the DNA (Temmink et al, 2005). 5fluorouracil can be anabolised to its active forms in two alternative pathways next to TK activation by uridine phosphorylase or orotate phosphoribosyltransferase, which seem the most important pathways (Peters, 2002). On the other hand, TFT is activated rapidly because it only needs one phosphorylation step in contrast to 5FU, and therefore TFT can be active against 5FU-resistant colorectal cancer cells (Murakami et al, 2000; Emura et al, 2004a). Thus, compared with 5FU, TFT is clearly a different drug than 5FU leading to different drug interactions. In general, 5FU combinations with cisplatin show variable interactions (Van der Wilt et al, 1992), whereas combinations of 5FU with OHP in general lead to synergistic interactions (Fischel et al, 1998). Our data clearly show synergism of TFT with OHP in all conditions.

Our data allow some preliminary conclusions about appropriate scheduling of OHP and TFT. Ideally, a combination should be at least additive in its anticancer effects but without excessive normal tissue toxicity. Oxaliplatin is administered by infusion, and in animals TAS-102 is orally administered and is most effective when used as a multiple daily dosing schedule (three times daily at $150 \mathrm{mg} \mathrm{kg}^{-1} \mathrm{day}^{-1}$ ) (Emura et al, 2004b, c). In human tumour 
xenografts in mice incorporation of TFT into DNA was significantly higher with divided dosing than single dosing, resulting in enhanced antitumour activity and no additional side effects. Regarding the TFT-OHP combination, we observed that preincubation with TFT resulted in less formation of Pt-DNA adducts and less subsequent induction of apoptosis than did simultaneous incubation without preincubation. The exact mechanism responsible for this decrease in formation of Pt-DNA adducts remains to be elucidated. Nonetheless, our data suggest that simultaneous incubation is ideal to maximise anti-tumour effects.

We studied both fixed and variable drug concentration ratios of TFT and OHP. Previous studies of drug combinations have often focused on a fixed ratio between the drug concentrations, but a fixed ratio does usually not reflect the actual ratio in patients (Van Moorsel et al, 1999; Temmink et al, 2006). Oxaliplatin and TFT show comparable growth inhibition curves (Figures 1 and 2), indicating the same growth inhibition kinetics. The synergism was observed at $\mathrm{FA}>0.5$. Although data at low drug concentrations suggest antagonism, we do not consider this part of the curve as relevant, since one aims to expose tumour cells to the highest possible cytotoxic drug concentration; this means that $25 \%$ growth inhibition is irrelevant, because this would mean that the tumour cell population still grows at $75 \%$ compared to untreated tumour cells. Our data are favourable for potential future application of this combination since synergism could be induced for both combination variants (fixed and variable ratios) for most cell lines. Trifluorothymidine has a $t_{1 / 2}$ of about $15 \mathrm{~min}$, but administration of several doses of TPI together with divided dosing of TFT increases the AUC and $t_{1 / 2}$ dramatically, which in turn could increase OHP-induced cytotoxicity when given simultaneously within the same time period. OHP is given by infusion and has a $t_{1 / 2}$ of less than 30 min (Ehrsson et al, 2002). This will result in a variable ratio, and therefore the variable ratio used in our experiments will better reflect a clinical situation.

Effects of combined OHP and TFT were cell line-dependent. The most significant results were obtained with the SW1116 cell line, which is the cell line most resistant to TFT. This is a promising perspective since combinations are aimed to reduce or bypass resistance. Trifluorothymidine enhanced OHP-induced cytotoxicity by increasng of the formation of Pt-DNA adducts (almost two-fold), which were well retained. This was accompanied by enhanced DNA-strand break formation, cell cycle arrest and subsequent apoptotic cell death, possibly mediated through caspase-3. Possibly because H630 is far more sensitive to both TFT and OHP than SW1116, the drug combination showed less pronounced effects compared with SW1116. The present study shows that no clear mechanism can be associated with the sensitivity to OHP or to the synergism between OHP and TFT. Platinum-DNA (Pt-DNA) adduct formation is enhanced, as well as DNA damage. However, with the comet assay it is difficult to assess the real tail moment values below five, and as it is not justified to add up the tail moments, one can only conclude that DNA damage is higher in the combination and is highest in the most synergistic cell line SW1116. In addition, on this cell line, the most pronounced changes in cell cycle distribution (increased $G_{2} M$ ) were found, possibly adding to the synergistic effect. This might be due to differences in TS levels or the incorporation rate of TFT in the cells. The present studies were also performed to see whether DNA damage repair was of any influence. The Western blot results showed that the protein expression levels of ERCC1, MLH1 and MSH2 DNA repair proteins do not correlate with the observed DNA damage induced by TFT-OHP. This was expected for MLH1 and MSH2 (DNA mismatch repair), which are mainly involved in the repair of cisplatin-induced DNA damage, not OHP-induced DNA damage. A possible increase of TFT incorporation into DNA by OHP might also interfere with the repair of OHP-induced DNA damage by ERCC1.

In conclusion, the combination of TFT with OHP is synergistic in colorectal cancer cells, which is related to increased Pt-DNA adduct formation and retention, cell cycle arrest and DNA damage induction. Therefore, our in vitro results provide a rationale for a clinical study of TAS-102 (TFT + TPI) together with OHP, with a potential value in the (second-line) treatment of colorectal cancer patients. Furthermore, the approval of the biological agents bevacizumab (Avastin ${ }^{\mathbb{R}}$ ) and cetuximab (Erbitux ${ }^{\mathbb{R}}$ ) might also be of interest for potential TAS-102-involving combinations, thereby enhancing inhibition of angiogenesis or targeting EGFR, respectively.

\section{ACKNOWLEDGEMENTS}

We thank Dr Jennette A Sakoff for the helpful discussions and for providing technical assistance regarding the DNA damage experiments. This study was financially supported by Taiho Pharmaceutical Co. Ltd, Tokushima, Japan.

\section{REFERENCES}

Andre T, De Gramont A (2004) An overview of adjuvant systemic chemotherapy for colon cancer. Clin Colorectal Cancer 4: S22-S28

Arango D, Wilson AJ, Shi Q, Corner GA, Aranes MJ, Nicholas C, Lesser M, Mariadason JM, Augenlicht LH (2004) Molecular mechanisms of action and prediction of response to oxaliplatin in colorectal cancer cells. $\mathrm{Br} \mathrm{J}$ Cancer 91: 1931 - 1946

Bergman AM, Ruiz van Haperen V, Veerman G, Kuiper CM, Peters GJ (1996) Synergistic interaction between cisplatin and gemcitabine in vitro. Clin Cancer Res 2: $521-530$

Bradford MM (1976) A rapid and sensitive method for the quantitation of microgram quantities of protein utilizing the principle of protein-dye binding. Anal Biochem 72: 248-254

Broker LE, Kruyt FA, Giaccone G (2005) Cell death independent of caspases: a review. Clin Cancer Res 11: $3155-3162$

Cassidy J, Tabernero J, Twelves C, Brunet R, Butts C, Conroy T, deBraud F, Figer A, Grossmann J, Sawada N, Schoffski P, Sobrero A, Van Cutsem E, Diaz-Rubio E (2004) XELOX (capecitabine plus oxaliplatin): active first-line therapy for patients with metastatic colorectal cancer. J Clin Oncol 22: 2084-2091

Chou TC, Talalay P (1984) Quantitative analysis of dose-effect relationships: the combined effects of multiple drugs or enzyme inhibitors. $A d v$ Enzyme Regul 22: $27-55$
Cloos J, Temmink O, Ceelen M, Snel MH, Leemans CR, Braakhuis BJ (2002) Involvement of cell cycle control in bleomycin-induced mutagen sensitivity. Environ Mol Mutagen 40: 79-84

Coutinho AK, Rocha Lima CM (2003) Metastatic colorectal cancer: systemic treatment in the new millennium. Cancer Control 10: 224-238

De Clercq E (2004) Antiviral drugs in current clinical use. J Clin Virol 30: $115-133$

Eckstein JW, Foster PG, Finer-Moore J, Wataya Y, Santi DV (1994) Mechanism-based inhibition of thymidylate synthase by 5-(trifluoromethyl)-2'-deoxyuridine 5'-monophosphate. Biochemistry 33: 15086-15094

Ehrsson H, Wallin I, Yachnin J (2002) Pharmacokinetics of oxaliplatin in humans. Med Oncol 19: 261-265

Emura T, Murakami Y, Nakagawa F, Fukushima M, Kitazato K (2004a) A novel antimetabolite, TAS-102 retains its effect on FU-related resistant cancer cells. Int J Mol Med 13: 545-549

Emura T, Nakagawa F, Fujioka A, Ohshimo H, Yokogawa T, Okabe H, Kitazato K (2004b) An optimal dosing schedule for a novel combination antimetabolite, TAS-102, based on its intracellular metabolism and its incorporation into DNA. Int J Mol Med 13: 249-255

Emura T, Suzuki N, Fujioka A, Ohshimo H, Fukushima M (2005) Potentiation of the antitumor activity of alpha, alpha, alpha-trifluorothymidine by the 
co-administration of an inhibitor of thymidine phosphorylase at a suitable molar ratio in vivo. Int J Oncol 27: 449-455

Emura T, Suzuki N, Yamaguchi M, Ohshimo H, Fukushima M (2004c) A novel combination antimetabolite, TAS-102, exhibits antitumor activity in FU-resistant human cancer cells through a mechanism involving FTD incorporation in DNA. Int J Oncol 25: 571-578

Faivre S, Chan D, Salinas R, Woynarowska B, Woynarowski JM (2003) DNA strand breaks and apoptosis induced by oxaliplatin in cancer cells. Biochem Pharmacol 66: 225-237

Fink D, Nebel S, Aebi S, Zheng H, Cenni B, Nehme A, Christen RD, Howell SB (1996) The role of DNA mismatch repair in platinum drug resistance. Cancer Res 56: $4881-4886$

Fischel JL, Etienne MC, Formento P, Milano G (1998) Search for the optimal schedule for the oxaliplatin/5-fluorouracil association modulated or not by folinic acid: preclinical data. Clin Cancer Res 4: $2529-2535$

Fishman AD, Wadler S (2001) Advances in the treatment of metastatic colorectal cancer. Clin Colorectal Cancer 1: 20-35

Fukushima M, Suzuki N, Emura T, Yano S, Kazuno H, Tada Y, Yamada Y, Asao T (2000) Structure and activity of specific inhibitors of thymidine phosphorylase to potentiate the function of antitumor $2^{\prime}$-deoxyribonucleosides. Biochem Pharmacol 59: 1227-1236

Goldberg RM, Sargent DJ, Morton RF, Fuchs CS, Ramanathan RK, Williamson SK, Findlay BP, Pitot HC, Alberts SR (2004) A randomized controlled trial of fluorouracil plus leucovorin, irinotecan, and oxaliplatin combinations in patients with previously untreated metastatic colorectal cancer. J Clin Oncol 22: 23-30

Grivicich I, Mans DR, Peters GJ, Schwartsmann G (2001) Irinotecan and oxaliplatin: an overview of the novel chemotherapeutic options for the treatment of advanced colorectal cancer. Braz J Med Biol Res 34: $1087-1103$

Hartley JM, Spanswick VJ, Gander M, Giacomini G, Whelan J, Souhami RL, Hartley JA (1999) Measurement of DNA cross-linking in patients on ifosfamide therapy using the single cell gel electrophoresis (comet) assay. Clin Cancer Res 5: 507-512

Hong DS, Abbruzzese JL, Bogaard K, Lassere Y, Fukushima M, Mita A, Kuwata K, Hoff PM (2006) Phase I study to determine the safety and pharmacokinetics of oral administration of TAS-102 in patients with solid tumors. Cancer 107: 1383-1390

Keepers YP, Pizao PE, Peters GJ, Ark-Otte J, Winograd B, Pinedo HM (1991) Comparison of the sulforhodamine B protein and tetrazolium (MTT) assays for in vitro chemosensitivity testing. Eur J Cancer 27: $897-900$

Maindrault-Goebel F, Louvet C, Andre T, Carola E, Lotz JP, Molitor JL, Garcia ML, Gilles-Amar V, Izrael V, Krulik M, De Gramont A (1999) Oxaliplatin added to the simplified bimonthly leucovorin and 5fluorouracil regimen as second-line therapy for metastatic colorectal cancer (FOLFOX6). GERCOR Eur J Cancer 35: 1338-1342

Matsushita S, Nitanda T, Furukawa T, Sumizawa T, Tani A, Nishimoto K, Akiba S, Miyadera K, Fukushima M, Yamada Y, Yoshida H, Kanzaki T, Akiyama S (1999) The effect of a thymidine phosphorylase inhibitor on angiogenesis and apoptosis in tumors. Cancer Res 59: 1911-1916

Moghaddam A, Bicknell R (1992) Expression of platelet-derived endothelial cell growth factor in Escherichia coli and confirmation of its thymidine phosphorylase activity. Biochemistry 31: 12141-12146

Murakami Y, Kazuno H, Emura T, Tsujimoto H, Suzuki N, Fukushima M (2000) Different mechanisms of acquired resistance to fluorinated pyrimidines in human colorectal cancer cells. Int J Oncol 17: 277-283

Olive PL (2002) The comet assay. An overview of techniques. Methods Mol Biol 203: $179-194$

Olive PL, Banath JP (1997) Multicell spheroid response to drugs predicted with the comet assay. Cancer Res 57: 5528-5533

Pelley RJ (2001) Oxaliplatin: a new agent for colorectal cancer. Curr Oncol Rep 3: $147-155$

Peters GJ (2002) Relative role of 5-fluorouracil activation and inactivation pathways on its cytotoxic effects. In Fluoropyrimidines in Cancer Therapy Rustum YM (ed) pp 1-27. Humana Press Inc, Totowa, NJ, USA

Peters GJ, Backus HH, Freemantle S, van Triest B, Codacci-Pisanelli G, van der Wilt CL, Smid K, Lunec J, Calvert AH, Marsh S, McLeod HL, Bloemena E, Meijer S, Jansen G, Van Groeningen CJ, Pinedo HM (2002) Induction of thymidylate synthase as a 5-fluorouracil resistance mechanism. Biochim Biophys Acta 1587: 194-205

Peters GJ, van der Wilt CL, Van Moorsel CJ, Kroep JR, Bergman AM, Ackland SP (2000) Basis for effective combination cancer chemotherapy with antimetabolites. Pharmacol Ther 87: 227-253
Pinedo HM, Peters GJ (1988) Fluorouracil: biochemistry and pharmacology. J Clin Oncol 6: 1653-1664

Raymond E, Buquet-Fagot C, Djelloul S, Mester J, Cvitkovic E, Allain P, Louvet C, Gespach C (1997) Antitumor activity of oxaliplatin in combination with 5-fluorouracil and the thymidylate synthase inhibitor AG337 in human colon, breast and ovarian cancers. Anticancer Drugs 8: $876-885$

Raymond E, Chaney SG, Taamma A, Cvitkovic E (1998a) Oxaliplatin: a review of preclinical and clinical studies. Ann Oncol 9: 1053-1071

Raymond E, Faivre S, Chaney S, Woynarowski J, Cvitkovic E (2002) Cellular and molecular pharmacology of oxaliplatin. Mol Cancer Ther 1: 227-235

Raymond E, Faivre S, Woynarowski JM, Chaney SG (1998b) Oxaliplatin: mechanism of action and antineoplastic activity. Semin Oncol 25: 4- 12

Raymond E, Lawrence R, Izbicka E, Faivre S, Von Hoff DD (1998c) Activity of oxaliplatin against human tumor colony-forming units. Clin Cancer Res 4: $1021-1029$

Rixe O, Ortuzar W, Alvarez M, Parker R, Reed E, Paull K, Fojo T (1996) Oxaliplatin, tetraplatin, cisplatin, and carboplatin: spectrum of activity in drug-resistant cell lines and in the cell lines of the National Cancer Institute's Anticancer Drug Screen panel. Biochem Pharmacol 52: $1855-1865$

Santi DV, Sakai TT (1972) Irreversible inhibition of thymidylate synthetase by 5 -formyl-2'-deoxyuridylic acid. Biochem Biophys Res Commun 46: $1320-1325$

Schmoll HJ, Buchele T, Grothey A, Dempke W (1999) Where do we stand with 5-fluorouracil? Semin Oncol 26: 589-605

Skehan P, Storeng R, Scudiero D, Monks A, McMahon J, Vistica D, Warren JT, Bokesch H, Kenney S, Boyd MR (1990) New colorimetric cytotoxicity assay for anticancer-drug screening. J Natl Cancer Inst 82: 1107-1112

Smorenburg CH, Peters GJ, Van Groeningen CJ, Noordhuis P, Smid K, van Riel AM, Dercksen W, Pinedo HM, Giaccone G (2006) Phase II study of tailored chemotherapy for advanced colorectal cancer with either 5fluorouracil and leucovorin or oxaliplatin and irinotecan based on the expression of thymidylate synthase and dihydropyrimidine dehydrogenase. Ann Oncol 17: 35-42

Sumizawa T, Furukawa T, Haraguchi M, Yoshimura A, Takeyasu A, Ishizawa M, Yamada Y, Akiyama S (1993) Thymidine phosphorylase activity associated with platelet-derived endothelial cell growth factor. J Biochem (Tokyo) 114: 9-14

Takahashi Y, Bucana CD, Akagi Y, Liu W, Cleary KR, Mai M, Ellis LM (1998) Significance of platelet-derived endothelial cell growth factor in the angiogenesis of human gastric cancer. Clin Cancer Res 4: 429-434

Takao S, Akiyama SI, Nakajo A, Yoh H, Kitazono M, Natsugoe S, Miyadera K, Fukushima M, Yamada Y, Aikou T (2000) Suppression of metastasis by thymidine phosphorylase inhibitor. Cancer Res 60: $5345-5348$

Tassone P, Tagliaferri P, Galea E, Palmieri C, Bonelli P, Martelli ML, Tuccillo F, Turco MC, Venuta S (2002) Oxaliplatin (L-OHP) treatment of human myeloma cells induces in vitro growth inhibition and apoptotic cell death. Eur J Cancer 38: 1141-1147

Temmink OH, Comijn EM, Fukushima M, Peters GJ (2004) Intracellular thymidylate synthase inhibition by trifluorothymidine in FM3A cells. Nucleosides, Nucleotides and Nucleic Acids 23: 1491 - 1494

Temmink OH, De Bruin M, Comijn EM, Fukushima M, Peters GJ (2005) Determinants of trifluorothymidine sensitivity and metabolism in colon and lung cancer cells. Anticancer Drugs 16: 285-292

Temmink OH, Hoogeland MF, Fukushima M, Peters GJ (2006) Low folate conditions may enhance the interaction of trifluorothymidine with antifolates in colon cancer cells. Cancer Chemother Pharmacol 57: $171-179$

Tsuchiya H, Kuwata K, Nagayama S, Yamashita K, Kamiya H, Harashima H (2004) Pharmacokinetic modeling of species-dependent enhanced bioavailability of trifluorothymidine by thymidine phosphorylase inhibitor. Drug Metab Pharmacokinet 19: 206-215

Vaisman A, Varchenko M, Umar A, Kunkel TA, Risinger JI, Barrett JC, Hamilton TC, Chaney SG (1998) The role of hMLH1, hMSH3, and hMSH6 defects in cisplatin and oxaliplatin resistance: correlation with replicative bypass of platinum-DNA adducts. Cancer Res 58: 3579-3585

Van der Wilt CL, van Laar JA, Gyergyay F, Smid K, Peters GJ (1992) Biochemical modification of the toxicity and the anti-tumour effect of 5fluorouracil and cis-platinum by WR-2721 in mice. Eur J Cancer 28A: 2017-2024

Van Moorsel CJ, Pinedo HM, Veerman G, Bergman AM, Kuiper CM, Vermorken JB, van der Vijgh WJ, Peters GJ (1999) Mechanisms of synergism between cisplatin and gemcitabine in ovarian and non-smallcell lung cancer cell lines. Br J Cancer 80: 981 -990 
Van Triest B, Pinedo HM, Giaccone G, Peters GJ (2000) Downstream molecular determinants of response to 5-fluorouracil and antifolate thymidylate synthase inhibitors. Ann Oncol 11: 385-391

Webley SD, Welsh SJ, Jackman AL, Aherne GW (2001) The ability to accumulate deoxyuridine triphosphate and cellular response to thymidylate synthase (TS) inhibition. $\mathrm{Br} J$ Cancer 85: $446-452$

Wolmark N, Wieand HS, Kuebler JP, Colangelo L, Smith RE (2005) A phase III trial comparing FULV to FULV + oxaliplatin in stage II or III

carcinoma of the colon: results of NSABP Protocol C-07. J Clin Oncol 23: 246s (Abstr \# 3500)

Woynarowski JM, Faivre S, Herzig MC, Arnett B, Chapman WG, Trevino AV, Raymond E, Chaney SG, Vaisman A, Varchenko M, Juniewicz PE (2000) Oxaliplatin-induced damage of cellular DNA. Mol Pharmacol 58: 920-927

Yang LY, Li L, Jiang H, Shen Y, Plunkett W (2000) Expression of ERCC1 antisense RNA abrogates gemicitabine-mediated cytotoxic synergism with cisplatin in human colon tumor cells defective in mismatch repair but proficient in nucleotide excision repair. Clin Cancer Res 6: 773-781 